\title{
Potensi Antibakteri Ekstrak Daun Lasianthus Terhadap Bakteri Pseudomonas aeruginosa
}

Penulis

Afiliasi

\section{R. Subekti Purwantoro ${ }^{1}$, Hartutiningsih-M. Siregar ${ }^{1 *}$, Sudarmono $^{1}$, Andria Agusta ${ }^{2}$}

\author{
${ }^{1}$ Pusat Konservasi Tumbuhan Kebun Raya, LIPI, Jl. Ir.H. Juanda 13 Bogor \\ ${ }^{2}$ Pusat Penelitian Biologi, LIPI, Cibinong Science Center
}

\section{Kata Kunci \\ $\rightarrow$ Lasianthus \\ - Pseudomonas aeruginosa \\ ○ Uji antibakteri}

Diterima 25 September 2014 Direvisi 28 Mei 2015 Disetujui 2 Desember 2016

*Penulis korespondensi Hartutiningsih-M.Siregar Pusat Konservasi Kebun Raya LIPI Jl. Juanda 13 Bogor Email:

hartutiningsih@yahoo.co.id

\section{ABSTRAK}

Penelitian ini bertujuan untuk mengetahui sifat antibiotik dari ekstrak tumbuhan Lasianthus terhadap aktivitas bakteri Pseudomonas aeruginosa secara in-vitro. Ekstrak yang diuji adalah daun Lasianthus laevigatus, L. furcatus, dan L. obscurus. Ekstraksi tumbuhan dilakukan secara maserasi bertingkat dengan menggunakan ekstrak $\mathrm{n}$ heksana, etil asetat, dan metanol. Potensi eskstrak sebagai antibakteri diuji melalui penghambatan aktivitas bakteri $P$. aeruginosa dengan menggunakan metode kertas cakram pada media agar Mueller-Hinton. Hasil penelitian menunjukkan bahwa ekstrak metanol pada daun $L$. furcatus memperlihatkan daya hambat tertinggi dengan zona hambat $12 \mathrm{~mm}$ (konsentrasi $50 \mu \mathrm{g}$ ), $19.5 \mathrm{~mm}$ (konsentrasi $100 \mu \mathrm{g}$ ), dan $20 \mathrm{~mm}$ (konsentrasi $200 \mu \mathrm{g}$ ), diikuti oleh L. obscurus dengan zona hambat $11 \mathrm{~mm}$ (konsentrasi $50 \mu \mathrm{g}$ ), $13 \mathrm{~mm}$ (konsentrasi $100 \mu \mathrm{g}$ ), dan $18.5 \mathrm{~mm}$ (konsentrasi $200 \mu \mathrm{g}$ ), sedangkan penggunaan ekstrak n-heksana dan etil asetat daya hambatnya rendah di bawah $10 \mathrm{~mm}$, terkecuali ekstrak $n$-heksana pada daun L. obscurus daya hambat tinggi dengan zona hambat $11 \mathrm{~mm}$ (konsentrasi $50 \mu \mathrm{g}$ ).

\section{PENDAHULUAN}

Pemanfaatan bahan alam yang berasal dari tumbuhan telah lama dilakukan oleh masyarakat Indonesia untuk menangani berbagai masalah kesehatan. Menurut Moeloek (2006) Indonesia merupakan negara tropis yang jenis-jenis tumbuhan berkhasiat obat melimpah. Dari 30.000 jenis tumbuhan obat 1.000 jenis yang baru ditemukan, sekitar 180 jenis sebagai bahan sediaan baru. Meskipun 76.5\% dari 9000 macam sediaan jamu telah terdaftar di BPOM merupakan produk nusantara, tetapi kalangan masyarakat menengah ke atas dan kalangan medis masih belum dapat menerimanya. Sangat penting upaya mengeksplorasi berbagai bahan alam alternatif lain untuk bahan industri farmasi yang akan datang mengantisipasi terjadinya kebutuhan bahan obat yang lebih banyak diperlukan. Suku kopi-kopian (Rubiaceae) merupakan salah satu anggota tumbuhan Angisopemae yang menghasilkan metabolit bioaktif dengan potensi farmakologi yang besar, bahkan metabolit pada kopi-kopian tersebut dapat digunakan sebagai penanda 
kemotaksonomi sampai tingkat marga dan sampai tingkat anak suku. Marga dari suku Rubiaceae yang mengandung metabolit bioaktif meliputi Uncaria, Psychotria, Hedyotis, Ophiorrhiza dan Morinda. Rubioideae adalah anak suku yang telah dikaji bioaktifnya terdiri 139 jenis; kajian jenis pada anak suku lainnya adalah Ixoroideae terdiri 80 jenis dan anak suku Cinchonoideae terdiri dari 74 jenis; Beberapa kandungan bioaktif yang ditemukan pada jenis-jenis Rubiaceae berupa iridoid, triterpen, alkaloid dan antrakuinon (Martins \& Nunez 2015).

Lasianthus adalah marga kopi-kopian yang juga berpotensi sebagai tumbuhan obat. Metabolit sekunder yang diperoleh dari Lasianthus termasuk senyawa antrakuinon, alkaloid, seskuiterpenoid, turunan secolupane, glikosida iridoid dan noniridoid, dll.; Sampai sekarang 47 konstituen kimia telah diisolasi dari jenis Lasianthus yang berbeda, beberapa di antaranya telah ditemukan terbukti ada aktivitas biologi secara signifikan (Choudhury et al. 2010). Bader et al. (2014) melaporkan bahwa hasil isolasi pada $L$. acuminatissimus ditemukan 2 senyawa iridoid glycosides yaitu asperuloside dan deacetyl asperuloside yang berkhasiat untuk pengobatan peradangan kronis pada sendi (rheumatoid arthritis). Menurut Martins \& Nunez (2015) 2 jenis Lasianthus yang mengandung komponen senyawa aktif adalah $L$. gardneri mengandung senyawa triterpenes: lupenon; lupeol; asam ursolik; asam kanarik; 3,4-seko-lupan, sedangkan L. wallichii mengandung Iridoid: iridolakton; iridoid dimer asperulosid; asam asperulosidik. Berdasarkan hasil wawancara dengan masyarakat di Cibodas Cianjur Jawa Barat Lasianthus dikenal dengan nama lokal "kahitutan" (Sunda) telah diketahui manfaatnya, Lasianthus laevigatus secara tradisional sering digunakan untuk mengobati masuk angin (Purwantoro et al. 2010). Menurut Rai \& Lalramnghinglova (2011) di India ada 2 jenis Lasianthus yang mempunyai khasiat obat, yaitu daun dari $L$. hirsutus dapat untuk menghentikan perdarahan pada masyarakat di wilayah Changneithing dalam bentuk jus, sedangkan di wilayah Ruih-thing rebusan daun $L$. wallichii dapat untuk pengobatan yang digolongkan sebagai obat halusinogen. Melati (2014) mengemukakan bahwa pengobatan dengan tumbuhan berkhasiat obat yang bersifat halusinogen dapat menimbulkan efek halusinasi yang bersifat merubah perasaan, pikiran dan sering kali menciptakan daya pandang yang berbeda sehingga seluruh perasaan dapat terganggu.
Bakteri $P$. aeruginosa merupakan bakteri patogen yang dapat menyebabkan berbagai gangguan kesehatan antara lain sepsis pneumonia, infeksi saluran kemih dan bakteremias juga dapat menyebabkan morbiditas dan mortalitas tinggi pada pasien dengan fibrosis kistik karena infeksi kronis yang akhirnya menyebabkan paru-paru mengalami kerusakan dan insufisiensi pernapasan (Ochoa et al. 2013). Menurut Rukmono \& Zuraida (2013) P. aeruginosa menyebabkan resistensi terhadap 14 macam obat antibiotik seperti antibiotik ampisilin, eritromisin, amoksisilin, sefurosim, seftriason, gentamisin, tetrasiklin, sefadroksil, piperasilin, trimetroprim, tobramisin, kotrimoksasol, nalidisid, sulfonamid kompleks.

Ciri-ciri Lasianthus mudah dikenal dengan karakter-karakter morfologi spesifik, antara lain: berperawakan semak tegak atau pohon kecil; letak daun tunggal bersebrangan berhadapan dengan pasangan daun penumpu; bunga hermafrodit, berukuran kecil posisi terletak pada ketiak daun; buah berdaging seperti beri, berwarna biru, hitam, jarang berwarna putih (Hua \& Taylor 2011), selanjutnya dilaporkan pula bahwa dari 184 jenis Lasianthus di dunia, 160 jenis ditemukan di Asia tropik. Penelitian ini bertujuan untuk mengetahui sifat antibiotik dari ekstrak beberapa jenis tumbuhan Lasianthus yang berasal dari Jawa Barat terhadap aktivitas biologi dari bakteri Pseudomonas aeruginosa secara in-vitro. Diharapkan hasil penelitian ini dapat melengkapi hasil penelitian sebelumnya senyawa-senyawa bioaktif potensial dari jenis-jenis tumbuhan Lasianthus sebagai senyawa antimikroba.

\section{METODE \\ Bahan}

Bahan penelitian fitokimia berupa sampel daun Lasianthus yang terdiri atas L. laevigatus dan L. furcatus (hutan G. Gede sekitar Kebun Raya Cibodas, LIPI pada bulan Juli 2009), L. obscurus (Hutan G. Ceremai pada bulan Agustus 2009) yang dipotong kecil-kecil dengan gunting stek kemudian dikeringkan di bawah sinar matahari, setelah kering kemudian dianalisis di Laboratorium Fitokimia, Bidang Botani, Puslit Biologi untuk uji antibakteri.

\section{Analisis Fitokimia Ekstraksi Bahan Tumbuhan}

Ekstraksi bahan tumbuhan dilakukan secara maserasi bertingkat menggunakan 3 jenis pelarut yaitu 
n-heksana, etil asetat dan metanol. Bahan kering masing-masing seberat $15 \mathrm{~g}$ direndam dengan $350 \mathrm{ml}$ n-heksana selama 24 jam, kemudian disaring dengan penyaringan kapas yang telah disiapkan sebelumnya. Filtrat yang dihasilkan dari penyaringan kemudian ditampung. Hal ini diulangi sampai 3 kali sampai filtrat yang tertampung jernih. Perlakuan yang sama juga dilakukan pada pelarut etil asetat dan metanol. Masing-masing ekstrak tersebut selanjutnya dipekatkan dengan rotary evaporator pada suhu $35{ }^{\circ} \mathrm{C}$. Ekstrak ditimbang untuk mengetahui rendemen ekstrak. Rendemen ekstrak adalah berat ekstrak dibagi dengan berat contoh dikalikan $100 \%$. Ekstrak yang diperoleh digunakan untuk uji efek antibakteri (Siregar et al. 2009).

\section{Uji Efek Antibakteri}

Ekstrak dari setiap tumbuhan diuapkan pelarutnya dengan rotary evaporator dan dikeringkan dengan gas $\mathrm{N}_{2}$. Masing-masing ekstrak selanjutnya dilarutkan di dalam aseton (untuk ekstrak $n$-heksana dan etil asetat) dan metanol (untuk ekstrak metanol) dengan konsentrasi $100 \mathrm{mg} / \mathrm{ml}(10 \mu \mathrm{g} / \mu \mathrm{l})$. Uji aktivitas antibakteria dilakukan dengan metoda cakram. Di atas kertas cakram yang telah disterilkan, dipipet sebanyak $5 \mu \mathrm{l}(50 \mu \mathrm{g}$ ekstrak), $10 \mu \mathrm{l}(100 \mu \mathrm{g})$ ekstrak), $20 \mu \mathrm{l}(200$ $\mu \mathrm{g}$ ekstrak) masing-masing ekstrak tumbuhan sampel, kemudian dikering anginkan selama 30 menit pada temperatur ruang di dalam laminar air flow untuk menghilangkan pelarut. Setelah dikeringkan kemudian diletakkan di atas medium agar Mueller-Hinton yang telah diinokulasi dengan bakteri uji Pseudomonas aeruginosa. Pengamatan aktivitas antibakteria dilakukan setelah 24 jam inkubasi pada temperatur 37 ${ }^{\circ} \mathrm{C}$. Aktivitas antibakteriz dari ekstrak uji ditandai dengan ada atau tidak zona bening yang terbentuk disekeliling ekstrak daun yang diteteskan di atas kertas cakram. Jarak zona bening dengan ekstrak daun yang ada di kertas cakram diukur dalam milimeter. Besar kecilnya diameter zona hambat menunjukkan tinggi rendahnya kemampuan ekstrak tanaman dalam menghambat pertumbuhan bakteri $P$. aeruginosa (Siregar et al. 2011).

\section{HASIL DAN PEMBAHASAN}

\section{Hasil}

Siregar et al. (2011) melaporkan bahwa daun $L$. laevigatus, L. furcatus, dan L. obscurus memiliki aktivitas antibakteri yang paling besar pada ekstrak metanol yaitu sebesar $11,2 \%, 8,5 \%$, dan 7,91 \%, kemudian diikuti ekstrak $n$-heksana yang dihasilkan pada daun $L$. laevigatus sebanyak $2,53 \%$, dan ekstrak etil asetat pada L. obscurus sebanyak 2,37 \%.Uji AntibakteriHasil uji antibakteri ekstrak n-heksana, etil asetat, dan metanol pada ekstrak daun Lasianthus terhadap $P$. aeruginosa menunjukkan ada aktivitas bioaktif. Secara in vitro ekstrak $n$-Heksana daun $L$. laevigatus pada medium agar Mueller-Hinton mampu menghambat pertumbuhan bakteri $P$. aeruginosa pada konsentrasi $100 \mu \mathrm{g}, 200 \mu \mathrm{g}$ dengan diameter zona hambat berturut-turut sebesar 8 dan $8.5 \mathrm{~mm}$, tetapi pada ekstrak etil asetat dan metanol tidak ada penghambatan pertumbuhan bakteri pada konsentrasi 50, 100, dan $200 \mu \mathrm{g}$. Keadaan demikian menunjukkan bahwa ekstrak daun yang bersifat non polar tersebut mempunyai kemampuan menghambat aktivitas bakteri P. aeruginosa, sedangkan pada daun $L$. furcatus hanya dapat menghambat pertumbuhan bakteri $P$. aeruginosa pada konsentrasi $50 \mu \mathrm{g}$, yaitu dengan zona hambat sebesar $7 \mathrm{~mm}$. Pada ekstrak etil asetat daun $L$. furcatus daya hambat pertumbuhan $P$. aeruginosa lebih kuat pada konsentrasi 50, 100, dan $200 \mu \mathrm{g}$ dengan zona hambat berturut-turut $8 \mathrm{~mm}, 9 \mathrm{~mm}$, dan $9.5 \mathrm{~mm}$, sementara itu juga terjadi aktivitas hambat pada konsentrasi $50 \mu \mathrm{g}$ dengan diameter zona hambat $11 \mathrm{~mm}$ pada daun L. obscurus. Ekstrak etil asetat daun L. furcatus mempunyai daya hambat yang lebih tinggi dari pada daya hambat ekstrak daun L. laevigatus. Pada ekstrak metanol yang memperlihatkan daya hambat tertinggi dibanding ekstrak etil asetat dan $n$-heksanol terjadi pada ekstrak daun L. furcatus dan L. obscurus. Ekstrak daun $L$. furcatus memperlihatkan daya hambat lebih tinggi dengan zona hambat $12 \mathrm{~mm}$ (konsentrasi $50 \mu \mathrm{g}$ ), 19,5 mm (konsentrasi $100 \mu \mathrm{g}$ ), dan $20 \mathrm{~mm}$ (konsentrasi $200 \mu \mathrm{g}$ ), diikuti oleh $L$. obscurus dengan zona hambat $11 \mathrm{~mm}$ (konsentrasi $50 \mu \mathrm{g}$ ), $13 \mathrm{~mm}$ (konsentrasi $100 \mu \mathrm{g}$ ), dan 18,5 mm (konsentrasi $200 \mu \mathrm{g}$ ) (Tabel 1). Praptiwi \& Harapini (2002) mengemukakan bahwa pada dosis 50, 100 dan $200 \mu \mathrm{g}$ sebagai dosis yang optimal untuk pengujian larutan $n$-heksana, etil asetat dan metanol. Aktivitas penghambatan pertumbuhan bakteri ditunjukkan pada Tabel 1 dan Gambar 1.

\section{Pembahasan}

Siregar et al. (2011) melaporkan hasil ekstraksi yang dilakukan secara maserasi bertingkat menunjukkan bahwa ekstrak metanol merupakan 
ekstrak yang paling tinggi rendemennya dibandingkan dengan ekstrak $n$-heksana dan etil asetat. Penemuan dengan rendemen yang tinggi juga terjadi pada beberapa jenis tanaman antara lain Quercus infectoria (Syukriah et al. 2014), Zingiber cassumunar (Hermansyah \& Utami 2015), Mangifera casturi (Firdausi 2015). Menurut Yuhernita \& Yuniarti (2011) pada ekstrak metanol yang rendemennya paling tinggi menunjukkan kandungan seyawa organik yang bersifat polar relatif besar dibandingkan $n$-heksanol dan etil asetat. Metanol adalah pelarut yang baik bagi substansi organik yang bersifat polar (Marcus \& Glikberg 1986). Sani et al. (2014) dalam penelitiannya pada Tetraselmis chuii mengemukakan bahwa pelarut berperan dalam menghasilkan rendemen yang tinggi karena pelarut yang digunakan memiliki sifat kepolaran yang sama dengan sebagian besar komponen yang terdapat pada biomassa sel seperti protein, karbohidrat dan klorofil.

Banyaknya total flavonoid yang diekstrak dengan pelarut etil asetat dikarenakan sifat dari etil asetat yang merupakan pelarut semi polar sehingga dapat menarik golongan-golongan flavonoid yang bersifat polar maupun nonpolar (Kanifah et al. 2015). Zuhud et al. (2001) menyatakan bahwa semakin tinggi konsentrasi ekstrak dan lama waktu kontak maka aktivitas antimikrobia ekstrak daun makin baik sehingga

Tabel 1. Diameter daerah hambat hasil uji antibakteri ekstrak daun Lasianthus terhadap bakteri $P$. aeruginosa

\begin{tabular}{rcccc} 
Ekstrak & Konsentrasi $(\mu \mathrm{g})$ & \multicolumn{3}{c}{ Diameter daerah hambat ekstraksi daun (mm) } \\
& 50 & L. laevigatus & L. furcatus & L. obscurus \\
\hline \multirow{3}{*}{ n-Heksana } & 100 & - & 7.0 & - \\
& 200 & 8.0 & - & - \\
Etil asetat & 50 & 8.5 & - & - \\
& 100 & - & 8.0 & 11.0 \\
Metanol & 200 & - & 9.0 & - \\
& 50 & - & 9.5 & - \\
& 100 & - & 12.0 & 11.0 \\
& 200 & - & 19.5 & 13.0 \\
\hline
\end{tabular}

Keterangan: "-“ tidak ada aktivitas antibakteri; diameter cakram 6 mm. Masing-masing uji diulang 2 kali

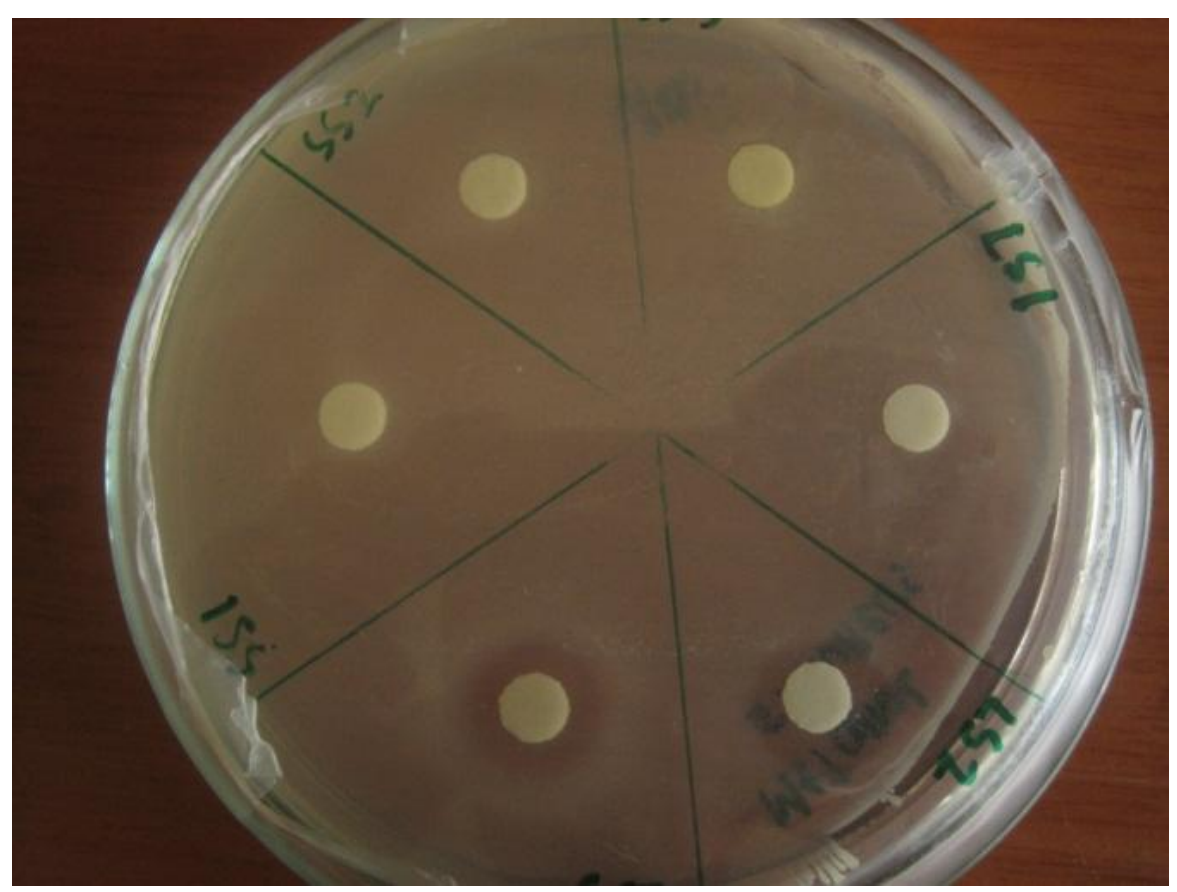

Gambar 1. Zona bening sekitar ekstrak daun Lasianthus menunjukkan hambatan pada aktivitas pertumbuhan bakteri $P$. aeruginosa 
mempermudah penetrasi senyawa tersebut ke dalam sel bakteri uji.

Bakteri $P$. aeruginosa lebih sensitif terhadap ekstrak metanol daun L. obscurus dari pada ekstrak daun Lasianthus lainnya. Hal ini diduga disebabkan oleh struktur dinding sel mengandung lipid pada bakteri, lemak atau substansi seperti lemak dalam persentase tinggi sebagai ciri khas bakteri gram negatif, di samping itu dinding sel bakteri yang tipis memperbesar permiabilitas dinding sel sehingga komponen yang bersifat antibakteri dapat lebih mudah menembus dinding sel bakteri.

Aktivitas antibakteri dari ekstrak daun Lasianthus tersebut dapat disebabkan senyawa aktif yang terkandung di dalamnya. Ekstraksi tumbuhan adalah proses penarikan zat aktif dalam tumbuhan dengan menggunakan pelarut tertentu. Ekstraksi tergantung pada tekstur dan kandungan bahan dalam tumbuhan. Senyawa/kandungan dalam tumbuhan memiliki sifat kelarutan yang berbeda-beda dalam masing-masing pelarut. Ekstraksi bertingkat biasanya dilakukan secara bertahap dimulai dengan pelarut yang bersifat nonpolar (kloroform atau n-heksana), semipolar (etilasetat atau dietil eter), dan terakhir dengan pelarut polar (metanol atau etanol) (Praptiwi \& Harapini 2004). Pada penelitian ini dapat diketahui bahwa kandungan senyawa kimia pada daun L. laevigatus, L. furcatus, dan L. obscurus bersifat non polar (n-heksana), semi polar (etil asetat), polar (metanol) dapat menghambat pertumbuhan bakteri $P$. aeruginosa (Tabel 1 ).

\section{SIMPULAN}

Berdasarkan hasil penelitian dapat disimpulkan bahwa ekstrak metanol pada daun $L$. furcatus mempunyai daya hambat paling tinggi dengan zona hambat $12 \mathrm{~mm}$ (konsentrasi $50 \mu \mathrm{g}$ ), $19.5 \mathrm{~mm}$ (konsentrasi $100 \mu \mathrm{g}$ ), dan $20 \mathrm{~mm}$ (konsentrasi $200 \mu \mathrm{g}$ ), diikuti oleh $L$. obscurus dengan zona hambat $11 \mathrm{~mm}$ (konsentrasi $50 \mu \mathrm{g}$ ), $13 \mathrm{~mm}$ (konsentrasi $100 \mu \mathrm{g}$ ), dan $18.5 \mathrm{~mm}$ (konsentrasi $200 \mu \mathrm{g}$ ). Penggunaan ekstrak nheksana dan etil asetat pada daun L. laevigatus dan $L$. furcatus daya hambatnya rendah dengan zona hambat di bawah $10 \mathrm{~mm}$, tetapi ekstrak n-heksana pada daun $L$. obscurus daya hambat tinggi dengan zona hambat 11 $\mathrm{mm}$ (konsentrasi $50 \mu \mathrm{g}$ ).

\section{UCAPAN TERIMA KASIH}

Ucapan terima kasih kami sampaikan kepada Kepala Pusat Konservasi Tumbuhan Kebun Raya Bogor:
Bp. Ir. Mustaid Siregar, MSi. melalui Proyek Insentif Riset untuk Peneliti dan Perekayasa: Kegiatan Sinergi Penelitian dan Pengembangan IImu Pengetahuan dan Teknologi DIKTI - LIPI 2009 atas dana yang diberikan untuk penelitian. Terima kasih diampaikan juga kepada Dr. Praptiwi yang telah bekerjasama sangat baik untuk kelancaran penelitian fitokimia, dan juga kepada Sdr. Elly K. Agustin, SP., Annisa Satyanti, M.Sc. dan rekanrekan di Unit Kerja Pembibitan Kebun Raya Bogor yang ikut dalam eksplorasi, membantu pemeliharaan hasil eksplorasi dan mengembangkannya, juga kepada rekan Slamet dan Rubono, staf dari Pembibitan Kebun Raya Bogor yang membantu kelancaran penelitian ini

\section{DAFTAR PUSTAKA}

Bader GN, Mir PA, Bhat ZA. 2014. Present status of antiinflammatory and antirheumatic phyoconstituents: a review. World Journal of Pharmacy And Pharmaceutical Sciences 3(11):272-310.

Choudhury KD, Choudhury MD, Talukdar AD. 2010. Chemical Constituents and Biological Activities of the Genus Lasianthus Jack: A Review. Assam University Journal of Science \& Technology: Biological and Environmental Sciences. 6(1):129138.

Firdausi I, Retnowati R, Sutrisno. 2015. Fraksinasi ekstrak metanol daun mangga kasturi (Mangifera casturi Kosterm) dengan pelarut nbutanol. Jurnal IImu Kimia Universitas Brawijaya. 1(1):785 - 790.

Hermansyah B, Utami WS. 2015 Bioactivity of a Compound of Standardized Bangle (Zingiber cassumunar Roxb.) Extract Fraction as a Complimentary Therapy to Prevent Malaria Complications. Journal of Agromedicine and Medical Sciences. 1(2):19-25.

Hua Z, Taylor CM. 2011. Lasianthus Jack. Flora of China. 19:185-198.

Kanifah U, Lutfi M, Susilo B. 2015. Karakterisasi ekstrak daun sirih merah (Piper crocatum) dengan metode ekstraksi non-thermal berbantukan ultrasonik (kajian perbandingan jenis pelarut dan lama ekstraksi). Jurnal Bioproses Komoditas Tropis. 3(1):73-79.

Melati R. 2014. Perilaku sosial remaja putri penyalahguna narkoba di Perumahan BTN Manggar Balikpapan Timur. eJournal IImu Sosiatri. 2(2):1-18. 
Marcus Y, Glikberg S. 1986. Recommended methods for the purification of solvents and tests for impurities methanol and ethanol. Pure and Applied Chemistry. 57(6):855-864.

Martins D, Nunez CV. 2015. Secondary Metabolites from Rubiaceae Species. Molecules. 20:1342213495.

Moeloek FA. 2006. Herbal and traditional medicine: National perspectives and policies in Indonesia. Jurnal Bahan Alam Indonesia. 5(1):293-297.

Ochoa SA, López-Montiel F, Escalona G, Cruz-Córdova A, Dávila LB, López-Martínez B, Jiménez-Tapia $Y$, Giono S, Eslava C, Hernández-Castro R, Xicohtencatl-Cortes J. 2013. Pathogenic characteristics of Pseudomonas aeruginosa strains resistant to carbapenems associated with biofilm formation. Boletín Médico del Hospital Infantil de México. 70(2):133-144.

Praptiwi, Harapini M. 2004. Pengujian antibakteri dan antioksidan ekstrak kulit batang siuri (Koordersiodendron pinnatum (Blanco) Merr.). Majalah Farmasi Indonesia. 15(3):151 - 157.

Praptiwi, Harapini M. 2002. Penapisan fitokimia dan ji anti bakteri secara in-vitro ekstrak kulit batang siuri (Koordersiodendron pinnatum). Laporan Teknik Pusat Penelitian Biologi-LIPI. DIPA TA 2002. Puslit Biologi LIPI Bogor.

Purwantoro RS, Siregar HM, Sudarmono, Praptiwi. 2010. Uji antibakteri Lasianthus (Rubiaceae) sebagai tumbuhan berkhasiat obat dan perbanyakannya. Buletin Kebun Raya. 13(2):8693.

Rahmawati N, Sudjarwo E, Widodo E. 2015. Uji aktivitas antibakteri ekstrak herbal terhadap bakteri Escherichia coli. Jurnal Ilmu-Ilmu Peternakan. 24(3):24 - 31.

Rai PK, Lalramnghinglova H. 2011. Ethnomedicinal plants of India with special reference to an IndoBurma Hotspot Region: an overview. Ethnonotany Research and Applications. 9:379420.

Rukmono P, Zuraida R. 2013. Uji Kepekaan Antibiotik Terhadap Pseudomonas aeruginosa penyebab sepsis neonatorum. Sari Pediatri 14(5):332-336.
Sani RN, Nisa FC, Andriani RD, Maligan JM. 2014. Analisis rendemen dan skrining fitokimia ekstrak etanol mikroalga laut, Tetraselmis chuii. Jurnal Pangan dan Agroindustri. 2(2):121-126.

Siregar HM, Purwantoro RS, Sudarmono, dan Agusta A. 2009. Pengungkapan Potensi Obat Pada Tiga Jenis Begonia Terpilih (B. muricata Blume, $B$. multangula Blume, $B$. "Bacem Kebo") Melalui Uji Antibakteri Escherichia coli Dan Staphylococcus aureus Secara In Vitro. Prosiding Seminar Nasional Sains II: Peningkatan Peran Sains Dalam Pertanian Dan Industri. Bogor, 14 November: 543-551. ISBN: 978-979-95093-5-2.

Siregar HM, Purwantoro RS, Sudarmono, Fijridiyanto IA, Satyanti A, Agusta A. 2011. Bio Pharmacy Potential of Begoniaceae (Begonia muricata Blume, B. multangu Blume, B. Baliensis Girmansyah) through In Vitro Antibacterial Test and Antifungal Test. Proceedings The $2^{\text {nd }}$ International Symposium on Temulawak. The $40^{\text {th }}$ Meeting of National of Working Group on Indonesian Medicinal Plant. Institute of Research and Community Services - Bogor Agricultural University INDONESIA: 190-195. ISBN No. 978979-25-1209-0.

Syukriah ARN, Liza MS, Harisun Y, Fadzillah AAM. 2014. Effect of solvent extraction on antioxidant and antibacterial activities from Quercus infectoria (Manjakani). International Food Research Journal. 21(3):1067-1073.

Yanuar A, Mun'im A, Lagho ABA, Syahdi RR, Rahmat M, Suhartanto H. 2011. Medicinal Plants Database and Three Dimensional Structure of the Chemical Compounds from Medicinal Plants in Indonesia. International Journal of Computer Science Issue. 8(1):180-183.

Yuhernita, Juniarti. 2011. Analisis senyawa metabolit sekunder dari ekstrak metanol daun surian yang berpotensi sebagai antioksidan. Makara Journal of Science. 15(10):48-52.

Zuhud EAM, Rahayu WP, Wijaya CH, Sari PP. 2001. Aktivitas Antimikroba Ekstrak Kedawung (Parkia roxburghii G. Don) terhadap Bakteri Patogen. Jurnal Teknologi dan Industri Pangan. 12 (1):612. 